\title{
The effect of concentrated bone broth as a dietary supplementation on bone healing in rabbits
}

\author{
Mahmood A. Aljumaily \\ Department of Surgery, College of Medicine, University of Mosul.
}

(Ann. Coll. Med. Mosul 2011; 37 (1 \& 2): 42-47).

Received: $25^{\text {th }}$ Aug 2010; Accepted: $18^{\text {th }}$ May 2011.

\begin{abstract}
Background: A variety of substances, biological and physical interventions have been used to enhance bone fractures healing. There is growing evidences for the importance of nutrition in maintenance of bone health and support of fracture healing.

Objective: The aim of this study was to evaluate the effect of the daily oral dose of concentrated bone broth as dietary supplementation on bone healing in experimental animals (rabbits).

Material and methods: Twelve young male rabbits divided into two groups after induction of open ulnar osteotomy, the experimental group receive daily dose of concentrated bone broth as a dietary supplementation. The control group received ordinary diet. In the end of second weeks three animals from both group were killed, at the end of fifth week, the other animals were sacrificed and the specimens taken for radiological and computerized tomography (CT) scan densimetry and histomorphometric evaluation carried out for the callus at site of osteotomy.

Results: The ulnar bone osteotomies in both groups were united at the end of the fifth week macroscopically and radiologically. The callus density was measured in site of osteotomy by CT scan densimetry, at the end of $2^{\text {nd }}$ week the difference between the experimental and control group was not significant, $(P$ value $>0.05)$, and at the end of $5^{\text {th }}$ week the difference between the experimental and control group was highly significant, $(P$ value $<0.001)$. The histomorphometric evaluation of healing in site of osteotomy carried out, and at the end of $2^{\text {nd }}$ week the difference between the experimental and control group was not significant, $(P$ value $>0.05)$, and at the end of $5^{\text {th }}$ week the difference between the experimental and control group was significant, $(P$ value $<0.05)$.

Conclusion: The present study demonstrate that a daily oral administration of concentrated bone broth as dietary supplementation in rabbits enhance bone healing by increase callus density in CT, and improve histomorphometric evaluation of healing.
\end{abstract}

Keywords: Bone broth, fracture, healing, and dietary supplementation.

$$
\begin{aligned}
& \text { الخلاصة } \\
& \text { الخلفية: استخدمت مواد كثيرة في محاولة تسريع وتحسين معدل التئام العظام. ظهرت معلومات متزايدة عن دور } \\
& \text { المضافات الغذائية لأجل تسريع التئام العظام. } \\
& \text { الأهداف: من أجل دراسة تأثير حساء العظام المركز كضاف التاف غذائي على التئام كسور العظام في الحيوانات المختبرية }
\end{aligned}
$$

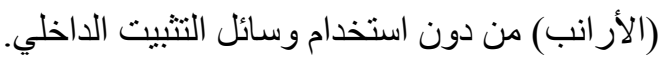

$$
\begin{aligned}
& \text { المواد وطريقة العمل: تم استخدام اثنا عشر من الأرانب النيوزلندية الذكور المكثرة محليا في هذه الدراسة. تمت هذه }
\end{aligned}
$$

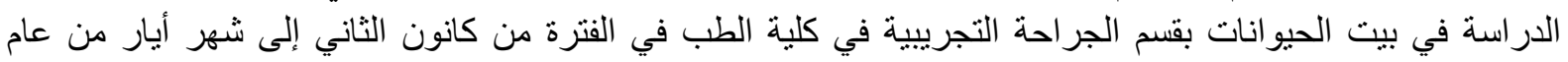

$$
\begin{aligned}
& \text { • • •r. تم إحداث كسر جراحي (قص العظم) في عظم الزند الأيمن بقطع جراحيا تحت التخدير العمومي وبواسطة }
\end{aligned}
$$

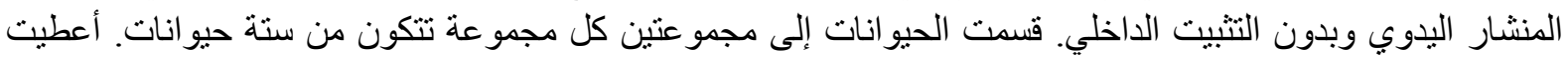


المجموعة الأولى جرعة يومية من حساء العظام المركز ، فيما كانت المجموعة عينة ضابطة. وبعد اسبو عين تم قتل ثلاثثة

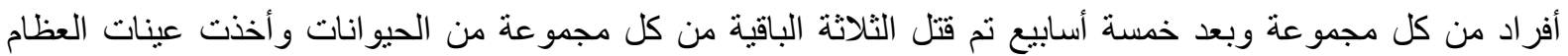
للفحص ألثعاعي وقياس كثافة العظم الملتئم بواسطة التصوير الطبقي المحوري وتم فحص نسيجي شكلي للعظم لتقدير درجة التنئام العظم في مكان قص العظم العظم. النتائج: التأمت كل العظام بعد قصها في نهاية الأسبوع الخامس ظاهريا و إثعاعيا. كان الفرق غير معنوي في معدل كثافة العظم الملتئم بواسطة التصوير الطبقي المحوري في محل القطع بعد أسبو عين في مجموعة التجربة. كان الفرقائ كانيان معنوي

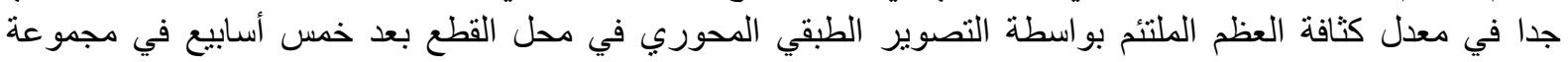

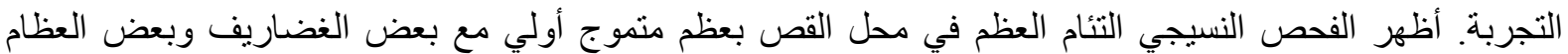
المكتملة. كان الفرق غير معنوي في معدل التنئام النسيجي الثكلي في موضع قص العظم بعد أسبوعين في مجموعة

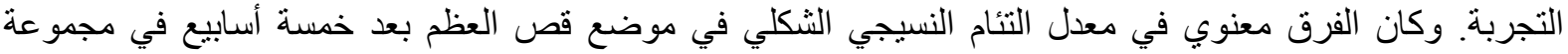
التجربة . الاستنتاج: إن هذه الدر اسة تبين بان إضافة مستخلص حساء العظام المركز كمضاف غذائي مع الغذاء اليومي للحيو انات المختبرية (الأرانب) المحدث لديها كسر في الزند الأيمن من دون استخدام وسائل التثبيت الداخلي يساعد في التئام كسور

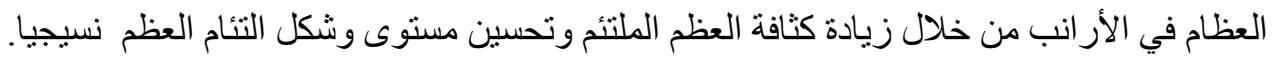

$\mathrm{T}$ raditional recipes for treatment of physical and mental illness exist in all major ancient civilizations of the world ${ }^{(1)}$. All cultures around the globe have used bone broth as part of their traditional dishes for centuries and used it as healing tonics for many ills ${ }^{(2)}$. The use of bone broth dietary supplementation by the common folk for promoting fracture healing process is an old practice in our community. Bone broth simply have met and stood the test of time within human cultures. Simmering bones in water extract many constituents contained in them like proteins, amino acids, glucosamine, hyaluronic acid, chondroitin sulphate, minerals, vitamins and other trace substances ${ }^{(2)}$. Bone broth is excellent source of minerals, since these naturally derived minerals are extracted from bone, they are in an ideal balance and easily utilized by the body ${ }^{(2)}$. By reviewing the available literatures, there were no registered studies on the effects of concentrated bone broth as dietary supplementation on bone healing.

Bone mineral density measurement by computerized tomography (CT) is noninvasive, and a reliable tool for quantification of the fracture repair process in experimental animals ${ }^{(3)}$. The mineral density of callus correlated positively with callus strength and stiffness ${ }^{(4)}$. Bone histomorphometry is a quantitative histological examination of decalcified and undecalcified bone biopsy performed to obtain quantitative information on bone remodeling and structure (5). Histomorphometric evaluation provides clear evidence of the healing process ${ }^{(6)}$. CT evaluations of bones show highly significant correlation with those determined using histomorphometry ${ }^{(7)}$.

The aim of this study was to evaluate the effect of the daily oral administration of concentrated bone broth as dietary supplementation on bone healing in experimental animals (rabbits).

\section{Material and methods}

This study was approved by the scientific research committee at the College of Medicine, University of Mosul, and follows the council for international organization of medical sciences ethical code for animal experimentation. Twelve young male aged 4 months locally breeded New Zeeland rabbits from animal house, College of Medicine, University of Mosul were used in this study at $1^{\text {st }}$ of November 2009 to 30 of April 2010. Their average weight 1470 grams ranged between1260 grams and 1520 grams. The animals were kept in separate metallic cages for one week for adaptation in animal's house. In each cage one animal feed with standard ration and water. 


\section{Bones broth preparation}

The bone extract done to some extent to that prepared by our population as bone soup given to patients. Fifty hundred grams of bone taken from bovine femoral head and neck, broken into pieces and cooked with 2 liters of distilled water in a pot for 4 hours, the bone removed and allowed to cool, and placed in refrigerator overnight for excess fat to congeal. The excess fat on surface of fluid removed, and the pot back on the stove and allowed to concentrate to $100 \mathrm{ml}$. The fluid stored in $4^{\circ} \mathrm{C}$, and three milliliters of concentrated broth mixed with animal daily diet of experimental group.

\section{Experimental technique}

Food was suspended eight to ten hours prior to administration of anesthesia. To decrease the vagal tonus, each animal received 0.2 $\mathrm{mg} / \mathrm{kg}$ dose of atropine sulphate by intramuscular injection. Animals were anesthetized by intramuscular injection of ketamine (50 mg/kg of body weight) and intramuscular injection of diazepam $(5.0 \mathrm{mg} / \mathrm{kg}$ of body weight). Preoperative antimicrobial prophylaxes consisting of $100 \mathrm{mg} / \mathrm{kg}$ of ceftriaxone were injected subcutaneously in proximal part of the same limb. Sample of venous blood aspirated to measure serum calcium, phosphate, and alkaline phosphatase.

The right forelimb was shaved and cleaned by betadine solution. Under aseptic techniques, the right ulna of each animal was accessed by an anterior longitudinal skin incision of approximately $20 \mathrm{~mm}$. After division of the skin and subcutaneous tissue, the fascia, the muscles and tendons were retracted and the periosteum was opened and dissected from the ulna. The ulnar shaft was exposed; osteotomy was performed on the exposed portion of the ulna by means of a one millimeter blade thickness sterile hand saw. The incision was closed, using absorbable 5-0 polyvycril sutures for the fascia and 4-0 monofilament PDS sutures for the skin, local dressing applied locally using sterile gauze covered with adhesive plaster. No surgical fixation or external splintage were used in these osteotomies.
The animals were assigned to two groups; the first group (6 animals) as experimental group received a daily dose of $3 \mathrm{ml}$ of concentrated bone broth as dietary supplementation in addition to their ordinary diet and continued for five weeks. The second group was the control group (6 animals) received ordinary diet. At the end of $2^{\text {nd }}$ week, 3 animals from each group were sacrificed, other 3 animals from each group were sacrificed at the end of $5^{\text {th }}$ week. Animals were anesthetized as described previously, a sample of blood aspirated to measure serum calcium, phosphate, and alkaline phosphatase, and killed with a $2 \mathrm{ml}$ intracardiac injection of potassium chloride. The right ulna of each animal was removed, dissected from the surrounding soft tissue and prepared for radiological, CT, and histological examination.

The samples examined radiologically by Siemen- Sirography fluoroscopy equipment 62 $\mathrm{K} . \mathrm{T}$.; the $\mathrm{KV}$ used in taking $\mathrm{x}$-ray was $30 \mathrm{KV}$, $50 \mathrm{~mA}$. The CT scan examination carried out to measure the density of callus at the site of osteotomy. The CT scan equipment was light speed, multidetector equipment, General Electric (GE), 32 Yokogawa Medical System, taken TA $0.6 \mathrm{~mm}$ slice thickness. The mean of five points taken at the site of osteotomy to measure the density of callus, the means and standard deviations of these values calculated.

The sites of osteotomy were carefully exposed by removal of all the soft tissue. The ulnar bones were removed, and fixed with 10\% formaldehyde solution. After fixation, they were decalcified in $10 \%$ foramic acid. The decalcification process demineralized the bone, leaving only the soft tissues and bone matrix. This was done to ensure that thin sections could be examined histologicaly. Thin sections embedded in paraffin wax were cut and stained with haematoxylin and eosin. The site of osteotomy examined histologically. The progression of fracture-healing in each specimen was quantified with the use of a scale that assigns a grade based on the relative percentages of fibrous tissue, cartilage, woven bone, and mature bone in the callus (histomorphometric evaluation) ${ }^{(8)}$. 
Grade 1 indicates fibrous tissue; grade 2, predominantly fibrous tissue with some cartilage; grade 3 , equal amounts of fibrous tissue and cartilage; grade 4, all cartilage; grade 5 , predominantly cartilage with some woven bone; grade 6 , equal amounts of cartilage and woven bone; grade 7 , predominantly woven bone with some cartilage; grade 8 , entirely woven bone; grade 9 , woven bone and some mature bone; and grade 10, lamellar (mature) bone. Five views were examined at site of osteotomy, and the mean of fracture healing scores were calculated for each group. The histomorphometric examination carried out in Al-Jumhori hospital laboratory. The grading was done blindly without knowing which treatment had been given.

\section{Statistical analysis}

Results were reported as mean \pm standard deviation. The unpaired student $(\mathrm{t})$ test used to calculate the differences between two means. The $P$ value was considered a significant if it was less than 0.05 .

\section{Results}

All animals survived to the end of the study. Neither wound infection nor wound dehiscence were observed in the animals of either group. All animal at time of osteotomy had normal serum calcium (the mean was $3.4 \pm 0.22$ $\mathrm{mmol} / \mathrm{dl}$ ), serum phosphate (the mean was $1.45 \pm 0.18 \mathrm{mmol} / \mathrm{dl}$ ), and serum alkaline phosphatase (the mean was $11.6 \pm 2.4 \mathrm{IU}$ unit/ dl). At the time of scarifying animals, the serum calcium was normal (the mean was $3.4 \pm 0.14$ $\mathrm{mmol} / \mathrm{dl}$ ), the serum phosphate was normal (the mean was $1.42 \pm 0.1 \mathrm{mmol} / \mathrm{dl}$ ), and serum alkaline phosphatase was normal (the mean was 12. $\pm 1.6 \mathrm{IU}$ unit/ dl). By using student (t) test to compare the differences between two mean, there was no statistically significant difference $(p>0.05)$ in the means of serum calcium, phosphate, alkaline phosphatase at starting experiment and at scarifying animals. Macroscopic evaluations demonstrate that all osteotomies were united completely by the end of $5^{\text {th }}$ week of the study, and there is soft callus in the end of $2^{\text {nd }}$ week in both groups. Radiological examination shows that osteotomies were at different stage of bone healing according to dating of scarification.

The callus density was measured in site of osteotomy by CT scan densimetry, its mean at the end of $2^{\text {nd }}$ week in the experimental group was $110.73 \pm 51.23$ and in the control group was $98.7 \pm 26.24$, the difference between the experimental and control group was not significant, $p$ value was 0.69 , ( $P$ value $>0.05$ ), at the end of $5^{\text {th }}$ week in the experimental group was $510.47 \pm 134$. 84 and in the control group was $261.13 \pm 70.03$, with $p$ value 0.0001 , the difference between the experimental and control group was highly significant, $(P$ value is $<0.05)$, (table 1$)$.

Table (1): Histomorphometric evaluation of bone healing and callus density evaluation by CT scan in site of osteotomy in experimental group and control group at the end of $2^{\text {nd }}$ and $5^{\text {th }}$ week.

\begin{tabular}{|c|c|c|c|c|c|c|c|}
\hline \multirow[b]{2}{*}{ Evaluation type } & \multirow{2}{*}{$\begin{array}{c}\text { Time of } \\
\text { end }\end{array}$} & \multicolumn{2}{|c|}{ Experimental group } & \multicolumn{2}{|c|}{ Control group } & \multirow[b]{2}{*}{$P$ value } & \multirow{2}{*}{$\begin{array}{l}\text { Significance of } \\
\text { difference }\end{array}$} \\
\hline & & mean & $\begin{array}{l}\text { Standard } \\
\text { deviation }\end{array}$ & mean & $\begin{array}{l}\text { Standard } \\
\text { deviation }\end{array}$ & & \\
\hline \multirow{2}{*}{$\begin{array}{l}\text { Histomorphometric } \\
\text { evaluation of bone } \\
\text { healing in site of } \\
\text { osteotomy }\end{array}$} & $\begin{array}{l}\text { At end } \\
\text { of } 2^{\text {nd }} \\
\text { week }\end{array}$ & 4.33 & 0.72 & 4.27 & 0.70 & 0.8 & Not significant \\
\hline & $\begin{array}{l}\text { At end } \\
\text { of } 5^{\text {th }} \\
\text { week }\end{array}$ & 7.67 & 0.62 & 7.03 & 0.74 & 0.04 & significant \\
\hline \multirow{2}{*}{$\begin{array}{l}\text { Callus density } \\
\text { evaluation by CT scan } \\
\text { in site of osteotomy }\end{array}$} & $\begin{array}{l}\text { At end } \\
\text { of } 2^{\text {nd }} \\
\text { week }\end{array}$ & 116.4 & 46.8 & 95.8 & 37.1 & 0.69 & Not significant \\
\hline & $\begin{array}{l}\text { At end } \\
\text { of } 5^{\text {th }} \\
\text { week }\end{array}$ & 510.47 & 134.84 & 261.13 & 70.03 & 0.001 & $\begin{array}{c}\text { Highly } \\
\text { significant. }\end{array}$ \\
\hline
\end{tabular}


The mean of histomorphometric evaluation of healing in site of osteotomy at the end of $2^{\text {nd }}$ week were $4.33 \pm 0.72$ in experimental group, while in control group were $4.27 \pm 0.70$, the $p$ value was 0.8 , the difference between the experimental and control group was not significant, $(P$ value $>0.05)$, and at the end of $5^{\text {th }}$ week were $7.67 \pm 0.62$ in experimental group while in control group were $7.13 \pm 0.74$, the $p$ value was 0.041 , the difference between the experimental and control group was significant, $(P$ value $<0.05)$, (table 1$)$. The Histopathological examinations of the osteotomy site shows healing bone at different stages according to time of bone harvesting, there is no evidence of infection or foreign body reaction in site of osteotomy.

\section{Discussion}

In this study, the concentrated bone broth shows highly significant increased the density of callus in CT densimetry measurement in site of osteotomy at the end of $5^{\text {th }}$ week in comparison with control group. The histomorphometric evaluation show significant improvement in healing process in site of osteotomy at the end of $5^{\text {th }}$ week in comparison with control group. At the end of $2^{\text {nd }}$ week the difference in CT callus density and histomorphometric evaluation was not significant between experimental and control group. Histopathological examination shows good union without complications (infection or giant cell reaction) in both groups. The findings in this study support the common folk idea that this dietary supplementation enhances bone healing when given in course of fracture healing for sufficient time. Bone broth, made from the bones of animals, has been consumed as a source of nourishment for humankind throughout the ages ${ }^{(2)}$. It is a traditional remedy across cultures for the sick and weak ${ }^{(2)}$.

There is growing evidences for the importance of nutrition in maintenance of bone and joint health ${ }^{(9)}$. Bone is complex tissue that requires many nutrients ${ }^{(10)}$. The recommended therapeutic supplementation includes about 20 bone building nutrients for acceleration of bone healing and to reduce complications $^{(10)}$. Multi-nutrient supplementat- ion includes proteins and amino acids, carbohydrates, fatty acids, antioxidants, calcium, phosphorus, vitamin D, fluoride, vitamin C, zinc, copper, magnesium, silicon, and trace of other substances, help in the acceleration of bone healing ${ }^{(9,11-16)}$. Strength of callus in the process of fracture healing depends on an adequate intake of dietary protein as well as an adequate supply of minerals ${ }^{(17)}$.

American Academy of Orthopedic Surgeons statement on animal use in experiments insists on: that the protocol should be designed to minimize the number of animals used ${ }^{(18)}$. The number of animals used in this experiment is sufficient to get a conclusion and to stimulate more wide clinical studies. The serum calcium, serum phosphate, serum alkaline phosphatase were normal in rabbits. This finding indicates that animals are healthy and had no systemic bone disease through all the time of study.

To compare the findings of our study with other studies, we reviewed the available scientific literatures. There were no registered studies on the effects of concentrated bone broth as dietary supplementation on bone healing, whither in experimental animals or in humans. Modern sciences are beginning to validate what tradition has valued for centuries. The bone broth is available, cheap, easy to be prepared, and can be very useful for patients in developing poor community with limited medical resources. Randomized prospective clinical studies indicated to support this finding in human.

In conclusion, this study demonstrates that concentrated bone broth as dietary supplementation improved significantly the healing process in rabbit's ulnar osteotomy, this effect characterized by increase callus density in CT, and improved results of histomorphometric evaluation in fracture healing.

\section{References}

1. Sanyal A, Ahmad A. Calcite growth in cissus quadrangularis plant extract, a traditional Indian bone healing aid. Current science 2005; 89:1742-5. 
2. Lieberman S. The Real Vitamins and Minerals Book. 2 ${ }^{\text {nd }}$. Ed. 1997. Avery publishing company. New York. : 162-95.

3. Nyman JS, Munoz S, Jadhav S, et al. Quantitative measures of femoral fracture repair in rats derived by micro-computed tomography. J Biomech. 2009; 42:891-7.

4. Shefelbine SJ, Simon U, Claes L, et al. prediction of fracture callus mechanical properties using micro-CT image and voxel-based finite element analysis. Bone 2005; 36: 480-8.

5. Goldschager T, Abdelkader A, Kerr J, Boundy J, Jenkin G. Undecalcified bone preparation for histology. Histomorphometry and flourochrome analysis. J Vist Exp. 2010; 8: 1707-20.

6. Yeom H, Blanchard S, Kim S, Zunt S, Chu TM. Correlation between micro- computed tomography and histomorphometry for assessment of new bone formation in a calvarial experimental model. J Craniofac Surg. 2008; 19: 446- 52.

7. Coret B, Chappard D, Boutry N, Dubois P, Cotton A, Marchandise X. Relationship between computed tomographic image analysis and histomorphometry for microarchitectural characterization of human calcaneus. Calcif Tissue Int. 2004; 75: 2331.

8. Aslan B, Kalaci A, Bozlar M, Atik E, Yanat A, Tasci A. Effect of vitamin D3 and calcium on fracture healing in rat. Turkiye Klinilleri J Med Sci. 2006; 26: 296- 302.

9. Sheweita SA, Kholshhal KL. Calcium metabolism and oxidative stress in bone fractures: role of antioxidants. Curr Drug Metab. 2007; 8: 519-25.
10. Eneroth M, Olsson UB, Thorngren KG. Nutrition supplementation decreases hip fracture-related complication. Clin Ortho and Related Res. 2006; 451:212-7.

11. Sinha S, Goel SC. Effect of amino acids lysine and arginine on fracture healing in rabbits. Indian J Orthop. 2009; 43:328- 39.

12. Polat O, Kilicoghs SS, Erdemli E. A controlled trail of glutamine effects on bone healing. Adv Ther. 2007; 24: 15460.

13. Tengstrand B, Cederholm T, Soderqvist A, Tidermark J. Effect of protein- rich supplementation and nandrolone on bone tissue after a hip fracture. Clin Nutr. 2007; 26: 460-5.

14. Cederholm T, Hedstrom M. Nutritional treatment of bone fracture. Curr Opin Clin Nutr Metab Care. 2005; 8: 377- 81.

15. Einhorn TA, Bonnarens F, Burstein AH. The contributions of dietary protein and minerals to the healing of experimental fractures. J Bone Joint Surg Am. 1986; 68: 1389-95.

16. Hughes MS, Kazmier $P$, Burd TA, et al. Enhanced fracture and soft tissue healing by means of anabolic dietary supplementation. J Bone Joint Surg Am. 2006; 88: 2386-94.

17. Kakar S, Einhorn TA. Importance of nutrition in fracture healing. In: nutrition and bone health. Ed. Holick MF, DawsonHughes B, Totowa NJ. 2004. Humana Press . In. New Jersey: 85- 103.

18. Golish SR, Jepsen K G, DeHart MM. Principle of practice and statistics. In: Miller M D. Review of orthopaedics. 2008. $5^{\text {th }}$ Ed. Saunders. Philadelphia.: $661-85$. 